\title{
Ajankohtaista aikuiskoulutuspolitiikasta
}

\author{
Seuraavassa on lyhyitä poimintoja \\ eräistä opetusministeriössä meneil- \\ lään olevista aikuiskoulutuspoliitti- \\ sista hankkeista. Valikko ei ole - ku- \\ ten kriittinen lukija huomaa - liki- \\ kään kattava.
}

\section{Parlamentaarinen aikuiskoulutustyöryhmä}

$\mathrm{O}$ petusministeriö asetti viime keväänä eduskunnan toivomuksesta parlamentaarisen aikuiskoulutustyöryhmän selvittämään - ei vähempää kuin - aikuiskoulutuksen koko kentän tavoitteita, kysynnän ja tarjonnan yhteensovittamista sekä rahoitusta. Kansliapäällikkö Markku Linnan johdolla työskentelevän työryhmän on määrä saada työnsä päätökseen tammikuun 2002 lopussa.

Työryhmän on määrä

- laatia selvitys aikuiskoulutuksen kokonaisuuden toimivuudesta ja työnjaosta

- arvioida, onko aikuisväestölle soveltuvaa koulutustarjontaa riittävästi ja vastaako se työelämän tarpeita ja aikuisten omia opiskelutavoitteita ja koulutukseen osallistumista

- arvioida aikuiskoulutusta tarjoavan koulutusverkoston tarkoituksenmukaisuutta, saavutettavuutta sekä toimintaa taloudellisuuden ja laadun näkökulmista

- tehdä ehdotuksia aikuiskoulutuspoliittisista kehittämislinjauksista niin, että otetaan huomioon väestön koulutustason nousu, ikärakenteen kehitys, elinikäisen oppimisen periaatteet, työllisyystavoitteet, työelämän tarpeet, aluepolitiikka ja kansainväliset vaikutukset

- tehdä ehdotuksia rahoituksen suuntaamisesta, resursseista ja rahoituspohjasta

Työryhmään kuuluu kansanedustajien lisäksi asiantuntijoina opetus- ja työhallinnon, työmarkkinajärjestöjen, kuntaliiton ja koulutuksen järjestäjien edustajat. Puheenjohtajana toimii kansanedustaja Jukka Gustafsson sekä sihteereinä Ville Heinonen, Merja Leinonen ja Matti Ropponen OPM:stä. Ks. työryhmän jäsenet www.minedu.fi.

\section{Ammattikorkeakoulujen jatkotutkintoja kokeillaan}

$\mathrm{V}$ altioneuvoston hyväksymän kehittämissuunnitelman mukaan käynnistetään ammattikorkeakoulujen jatkotutkintokokeilu. Sitä koskeva laki astuu voimaan ensi vuoden alussa. Suunnitelmana on saada aikaan 40-60 opintoviikon laajuiset jatkotutkinnot. Kysymyksessä on siis uusi korkeakoulututkinto, minkä tarkoituksena on antaa riittävää tieto- ja taitoperustaa ja valmiuksia erityisesti asiantuntemusta vaativissa työelämän kehittämistehtävissä. Tutkinto on tarkoitettu henkilöille, joilla on ammattikorkeakoulututkinto tai muu soveltuva korkeakoulututkinto sekä vähintään kolmen vuoden työkokemus asianomaiselta alalta tutkinnon suorittamisen jälkeen.

Kokeilu käynnistetään muutamissa koulutusohjelmissa hallinnon ja kaupan (pk-sektorin yrittäjyyden ja liiketoimintaosaamisen koulutusohjelma), sosiaali- ja terveysalan (ikääntyvien ja pitkäaikaispotilaiden hoidon koulutusohjelma sekä terveyden edistämisen ja ehkäisevän työn koulutusohjelma) sekä tekniikan ja liikenteen aloilla (korjaus- ja täydennysrakentamisen koulutusohjelma ja hyvinvointiteknologian koulutusohjelma). Ammattikorkeakoulut jättivät määräaikaan mennessä (31.10.) 53 esitystä jatkotutkintokokeiluiksi. Korkeakoulujen arviointineuvosto tekee niistä oman esityksensä vuoden loppuun mennessä, minkä pohjalta opetusministeriö tekee kokeilulupapäätöksensä helmikuun 2002 loppuun mennessä. Jatkotutkintokoulutus voi alkaa ensi vuoden elokuun alussa.

\section{Opintoluotsi luotsaa ja neuvoo}

$\mathrm{O}$ petusministeriössä on valmisteilla Internetissä toimiva Opintoluotsi. Se on linkkihakemisto, mistä on määrä löytyä kattavasti tarjolla olevat opiskelumahdollisuudet. Yhtenä etsintävalikko opastaa koulutukseen sen mukaan, tavoitteleeko hakija tutkintoa, osaamista työelämässä, opiskelua harrastuksena, etsiikö hän opiskelumahdollisuuksia ulkomailla tai hakeeko hän 
vammaisille tarkoitettua erityiskoulutusta tai kenties ulkomaalaisille tarkoitettua koulutusta. Yksi etsintävalikko ryhmitellään koulutusaloittain ja kolmas oppilaitoksittain. Apua on määrä saada myös rahoitus- ja asunto-ongelmissa, verkkoopiskelussa, aputoiminnoissa tai opiskelumuodon valinnassa.

\section{Aikuiskoulutuksen laatupalkinto}

$\mathrm{O}$ PM:n perustama, uutukainen Aikuiskoulutuksen laatupalkinto julkistetaan ja luovutetaan 17.12. Palkinnon tarkoituksena on

- kannustaa aikuiskoulutuksen järjestäjiä kehittämään omaa toimintaansa ja itsearviointia

- tehdä tunnetuksi korkealaatuisia, uusia, in novatiivisia, vaikuttavia ja aikuisopiskelun kannalta onnistuneita käytäntöjä, joita muutkin voivat soveltaa koulutuksessaan

- edistää aikuisopiskelua ja elinikäistä oppimista sekä

- lisätä aikuisopiskelun yhteiskunnallista arvostusta.

Laatupalkintoa haki yli 50 koulutuksen järjestäjää. Hakijat on nähtävissä netistä osoitteesta www.minedu.fi. Arvoltaan palkinto on 100000 markkaa.

\section{Opintosetelikokeilu}

$\mathrm{K}^{2}$ ansalais- ja työväenopistoliike sen aloitti, opintosetelikokeilun. Kuluneesta syksystä alkaen takana on ollut myös opetusministeriö, joka myönsi pilottikokeilua varten avustukset Tuusulalle, Mikkelille, Kuusankoskelle, Porille ja Kittilälle. Kukin kunta saa käyttöönsä 300 kappaletta 500 markan arvoisia opintoseteleitä, mitkä on tarkoitettu tietotekniikan peruskurssitasoiseen opiskeluun. Opintosetelit, joita vastaan siis saa koulutusta, jaettiin pääosin työvoimatoimistojen kautta.

500 markan suuruisella opintosetelillä tuetaan ensi vaiheessa erityisesti tietotekniikan perustaitojen hankkimista. Kohderyhminä ovat työttömät, yli 60-vuotiaat ja maahanmuuttajat. Setelin voi käyttää opinnoista perittäviksi maksuiksi valituissa oppilaitoksissa. Kokeilua on tarkoitus laajentaa vuonna 2002 saadut kokemukset huomioonottaen.
Opintosetelikokeilua valmisteli työryhmä, johon kuuluivat opetusneuvos Arja Mäkeläinen OPM:stä, hallintoneuvos Hannu Hakkola sosiaali- ja terveysministeriöstä, ylitarkastaja Markku Virtanen työministeriöstä, rehtori Pentti Silvennoinen Pietarsaaren työväenopistosta sekä toiminnanjohtaja Eeva-Inkeri Sirelius Kansalais- ja työväenopistojen liitosta. Työryhmän raportti on kokonaisuudessaan luettavissa OPM:n nettisivulta www.minedu.fi/julkaisut/pdf/opintoseteli.pdf.

\section{Koulutuspoliittinen selonteko}

$\mathrm{O}$ petusministeriön asettama työryhmä puheenjohtajanaan lainsäädäntöneuvos Matti Lahtinen valmistelee ehdotusta hallituksen koulutuspoliittiseksi selonteoksi, joka on määrä esitellä eduskunnalle ensi maaliskuun lopussa. Kysymyksessä on eduskunnan pyytämä selonteko, jonka sen tulee saada kolmen vuoden kuluttua koululakien voimaantulosta. Selonteon tarkoituksena on tarkastella uusien lakien vaikutusta.

\section{Tärkeitä arvioita ja tutkimuksia tulossa heti vuoden 2002 alussa}

Suomen aikuiskoulutuspolitiikasta ja aikuisten osallistumisesta erilaisiin opintoihin valmistuu kiinnostavia arvioita ja tutkimuksia heti vuoden 2002 alussa. Suomen aikuiskoulutuspolitiikan OECD-tutkinnan keskeiset julkaisut eli maaraportti ja OECD-asiantuntijaryhmän raportti julkaistaan opetusministeriön julkaisusarjassa alkuvuodesta. Aikuiskasvatus-lehti kertoo raporttien keskeisistä asiasisällöistä julkaisemalla numerossa 1/ 2002 opetusneuvos JoRMA AHOLAN haastattelun.

Opetusministeriön rahoittama Aikuiskoulutustutkimus 2000 antaa monipuolisesti tietoa kansalaisten opiskelusta sekä osallistumista edistävistä ja estävistä tekijöistä. Siinä osallistuminen on tilastoitu sektoreittain. Vapaan sivistystoiminnan osalta saadaan ensimmäistä kertaa todelliset luvut siitä, kuinka moni suomalainen osallistuu koulutukseen. Tilastokeskuksen julkaisu valmistuu kevään 2002 aikana. Ennakkotiedot ovat kuitenkin nähtävissä jo nyt Tilastokeskuksen kotisivuilla.

Lisää: www.minedu.fi/, www.tilastokeskus.fi tai etunimi.sukunimi@minedu.fi 